\title{
Pinocembrin-7-Glucoside (P7G) Reduced Postharvest Blue Mold of Navel Orange by Suppressing Penicillium italicum Growth
}

\author{
Chuying Chen ${ }^{1} \mathbb{D}$, Jinyin Chen ${ }^{1,2, * \mathbb{C}}$ and Chunpeng Wan ${ }^{1, *} \mathbb{C}$ \\ 1 Jiangxi Key Laboratory for Postharvest Technology and Non-destructive Testing of Fruits \& \\ Vegetables/Collaborative Innovation Center of Postharvest Key Technology and Quality Safety of Fruit and \\ Vegetables, College of Agronomy, Jiangxi Agricultural University, Nanchang 330045, China; \\ cy.chen@jxau.edu.cn \\ 2 Pingxiang University, Pingxiang 337055, China \\ * Correspondence: jinyinchen@126.com (J.C.); chunpengwan@jxau.edu.cn (C.W.); \\ Tel.: +86-791-83813158 (J.C. \& C.W.)
}

Received: 26 February 2020; Accepted: 6 April 2020; Published: 8 April 2020

\begin{abstract}
The current study aimed to examine the in vitro and in vivo antifungal potential of pinocembrin-7-glucoside (P7G). P7G is an antifungal flavanone glycoside isolated from Ficus hirta Vahl. fruit against Penicillium italicum, a causative pathogen of blue mold disease in citrus fruit, and this study elucidates its possible action mechanism. P7G had a prominent mycelial growth inhibitory activity against $P$. italicum, with an observed half maximal effective concentration, minimum inhibitory concentration and minimum fungicidal concentration of $0.08,0.2$, and $0.8 \mathrm{~g} / \mathrm{L}$, respectively. The data from the in vivo test show that P7G significantly reduced blue mold symptoms and disease development of $P$. italicum in artificially inoculated "Newhall" navel orange. Compared to the control, increases in the cell membrane permeability of P. italicum supernatant and decreases in the intracellular constituent (e.g., soluble protein, reducing sugar, and total lipid) contents of P. italicum mycelia were identified, supporting scanning electron microscopy and transmission electron microscopy observations. Furthermore, a marked decline in both chitin and glucanase contents of P. italicum mycelia treated with P7G was induced by increasing its related degrading enzyme activities, suggesting that the cell wall structure was destroyed. The current study indicated that P7G may be a novel alternative for reducing blue mold by suppressing mycelial growth of $P$. italicum via a cell membrane/wall-targeting mechanism.
\end{abstract}

Keywords: pinocembrin-7-glucoside; blue mold; navel orange; Penicillium italicum; antifungal activity

\section{Introduction}

By far, China is the largest country in the world in terms of both citrus yield and cultivated area, and it has a large variety of species and varieties, such as loose-skin mandarin, sweet orange, pummelo, kumquat, lemon, grapefruit, citron, and different special hybrids [1,2]. The postharvest nutritional quality and storage life of citrus fruit were limited by a variety of fungal diseases, including citrus blue mold (Penicillium italicum), green mold (Penicillium digitatum), sour rot (Geotrichum citri-aurantii), brown spot (Alternaria alternata), stem-end rot (Diaporthe citri), and black spot (Phyllosticta citricarpa) [3-7]. Among them, blue mold is the primary postharvest disease that causes $20-50 \%$ of citrus fruit loss in China during postharvest disposal [3]. In past decades, some commercial fungicides such as imazalil, prochloraz, or thiabendazole have been the primary means of controlling these diseases [8-10]. However, increasing public concerns regarding chemical residues on human health, environmental pollution, and resistance pathogens due to excessive use of chemical fungicides have initiated an investigation 
into alternative strategies for reducing postharvest fungal decay without any human, environmental, or plant toxicity [11-13]. Recently, a huge number of studies have documented the antifungal effects of plant-derived natural compounds, generally regarded as safe (GRAS) substances, for controlling postharvest blue mold caused by P. italicum incurring serious deterioration of citrus fruit.

Ficus hirta Vahl. (family of Moraceae) fruits, which are also called "wǔ zhǐ Máo Táo guǒ", are used as medicine and edible food for the treatment of constipation, inflammation, postpartum hypogalactia, tumors, and cancers by Hakka people in Southern China [14-17]. In our previous study, we reported that the ethanol extracts from $F$. hirta Vahl. fruits displayed prominent antifungal activity against P. italicum, P. digitatum, A. citri, G. citri-aurantii, and other pathogens in vitro [18]. Particularly, the ethanol extract of $F$. hirta Vahl. fruits was found to be able to control postharvest blue mold decay and to improve the preservation effects of "Newhall" navel oranges, "97-2" Nangfeng mandarins and "Xinyu" tangerines [19-21]. Correspondingly, the extract of F. hirta Vahl. fruits might be developed into a natural alternative to the traditional fungicides for controlling postharvest fungal diseases of horticultural crops.

Flavonoid glycosides are a group of flavonoids mainly isolated from some plant tissues, such as Astragalus membranaceus leaves, Ficus hirta Vahl. fruits, Lilium lancifolium flowers, poplar buds, and Plinia cauliflora leaves [22-26], and are known for their potent antifungal activity, which occurs through a lipid peroxidation mechanism. In our previous research, pinocembrin-7-glucoside (P7G; Figure 1) or pinocembroside, one of the flavonoid glycosides, was isolated as one of the major antifungal compounds in Ficus hirta Vahl. fruits [23]. Recently, P7G has become the focus of increased attention due to its strong preventive effects against hepatic steatosis and its prominent protective effects against ethanol-induced liver injury $[26,27]$. A previous study which bore out the antifungal activity of P7G on P. italicum in potato dextrose agar (PDA) media showed that P7G was successful at inhibiting both Penicillium spp. mycelial growth $[23,28,29]$.

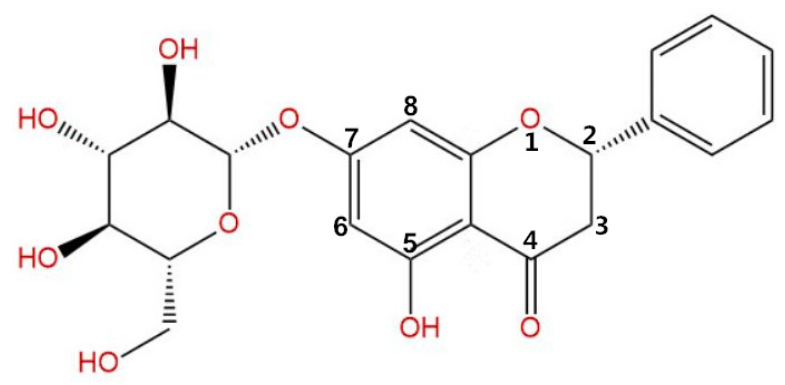

Figure 1. Chemical structure of pinocembrin-7-glucoside (P7G).

However, to date, there have been no reports on the antifungal activity and possible action mechanisms of P7G on postharvest pathogenic fungus in citrus fruit, especially those concerning P. italicum, which infects fresh citrus fruit. Therefore, the present study aimed to evaluate the antifungal activity of P7G against $P$. italicum both in vitro and in vivo tests. Moreover, focus on the possible mechanisms involving morphological changes, intracellular constituent losses and plasma membrane permeability in P. italicum were also studied.

\section{Materials and Methods}

\subsection{Fruit Material}

Navel oranges (Citrus sinensis L., Osbeck cv. Newhall) were hand-harvested by the end of November 2017 at a local orchard in Anyuan County, situated in the Southeast of Ganzhou city (Jiangxi Province), China. The physiologically mature fruits were chosen by keeping in mind the health and size (240-280 g) of the fruit, identical color (citrus color index: CCI, 5.8-7.0), and the lack of any bruises and disease symptoms. 


\subsection{Phytopathogenic Fungi Isolation}

The phytopathogenic fungi of P. italicum P. digitatum, G. citri-aurantii, A. citri, D. citri, and Colletotrichum gloeosporioides were taken from the rotted citrus fruits with representative disease symptoms of blue mold, green mold, sour rot, black rot, stem-end rot, and anthracnose, and were properly identified by using DNA sequencing done by the National Center for Industrial Culture Collection (CICC) of China. The pure fungi were expanded on a PDA medium at $25 \pm 1{ }^{\circ} \mathrm{C}$. On day seven of culturing, the P. italicum spore suspension was collected, filtered, and set at the optimum level of $1.0 \times 10^{6} \mathrm{CFU} / \mathrm{mL}$ using a Countess-II FL automatic cell counter.

\subsection{P7G Isolation and Purification}

The P7G with $92.57 \%$ purity used in the current study, originally isolated from F. hirta Vahl. fruits [23], was suspended in $80 \%$ ethanol to obtain a stock solution of $10 \mathrm{~g} / \mathrm{L}$.

\subsection{In Vitro Antifungal Activity Assay}

\subsubsection{Minimal Inhibitory Concentration (MIC) and Minimum Fungicidal Concentration (MFC)}

Both minimal inhibitory concentration (MIC) and minimum fungicidal concentration (MFC) were evaluated following our previous method reported by Chen et al. [29], where the MIC and MFC values were considered as the lowest concentration of P7G that completely inhibited mycelial growth of six tested phytopathogenic fungi after incubation for 2 and 6 days, respectively.

\subsubsection{Assay of P7G on Mycelial Growth of P. italicum}

The antifungal properties of P7G on mycelial growth of P. italicum were identified according to our previously described method $[3,28]$. In short, the stock solution of P7G was further diluted using an optimum quantity of $0.5 \%$ sterile Tween 80 , and then mixed up in PDA to make a range of dilutions $(0,0.025,0.05,0.1,0.2,0.4$, and $0.8 \mathrm{~g} / \mathrm{L})$. Afterward, a 5-mm-diameter mycelial disk, cut from the periphery of 7-day-old culture of P. italicum, was dropped on the center of each PDA dish. After incubation at $25^{\circ} \mathrm{C}$ in the dark for 7 days, the colony diameters of these dishes were measured, and the inhibitory rate of P. italicum growth was calculated according to the formula: (the mean colony diameter of control set-the mean colony diameter of P7G-treated set)/ the mean colony diameter of control set $\times 100$. Each treatment and control group were replicated four times, and the experiment was carried out separately twice. The half maximal effective concentration was expressed as $\mathrm{EC}_{50}$ (with the P7G-treated concentration effectively inhibiting growth rate by $50 \%$ ) and calculated based on the linear regression of the mycelial growth inhibition (MGI) on the log-transformed P7G concentrations [29].

\subsubsection{Assay of P7G on Spore Germination of P. italicum}

The antifungal stability of P7G was determined by the spore germination assay according to the method we reported in a previous study [3]. Briefly, the tested P. italicum strain was grown on PDA plate medium at $25^{\circ} \mathrm{C}$ for 7 days. P7G was prepared by dissolving moderate amounts in sterile $0.5 \%$ Tween 80 , and individually diluted with potato dextrose broth (PDB) to obtain a series of concentrations $(0,0.025,0.05,0.1,0.2,0.4$, and $0.8 \mathrm{~g} / \mathrm{L})$. Afterward, $5 \mu \mathrm{L}$ of $P$. italicum spore suspension was added into both the control (0-concentrate) and P7G-treated slides. After incubation at $25^{\circ} \mathrm{C}$ in the dark for $14 \mathrm{~h}$, approximately 100 spores per replicate were microscopically observed, and the germination inhibitory rate of $P$. italicum spore was calculated according to the formula: (the mean amount of germinated spore in the control slide- the mean amount of germinated spore in the P7G-treated slide)/ the mean amount of germinated spore in the control slide $\times 100$. Each treatment and control group was replicated four times, and the experiment was carried out separately twice. 


\subsection{In Vivo Antifungal Activity Assay on Navel Orange Fruit}

The effects of P7G on lesion diameter and disease severity in navel oranges were determined following the method previously described with slight modifications [30,31]. The sterilized navel oranges were wounded ( $4 \mathrm{~mm}$ diameter and 2-mm deep) using a sterile puncher at the equatorial side on each fruit, and then divided in five randomized groups for various P7G treatment levels $(0,1,2,4$, and $8 \mathrm{~g} / \mathrm{L}$ ). About $20 \mu \mathrm{L}$ of solutions either containing P7G or not (the control) were injected into each wound on the citrus fruit. After air-drying for $30 \mathrm{~min}$, an equal volume of fungal spore suspension $\left(5 \times 10^{4} \mathrm{CFU} / \mathrm{mL}\right)$ was also injected in each respective wound of the citrus fruit. All fruits were then put in containers $(45 \times 36 \mathrm{~cm}$ polyethylene-lined plastic frames) which maintained higher relative humidity levels (90-95\%) at $25^{\circ} \mathrm{C}$. The lesion diameter and disease severity of the P7G-treated and the control fruits' wounds were observed at 3, 5, and 7 days post-inoculation. Three replicates of 30 fruits were used per treatment, and the experiment was performed twice. The lesion diameter was measured by the cross method using a Vernier caliper. The disease severity was evaluated and expressed as a percentage following a previously described method [30].

\subsection{Microscopic Observations}

The effects of P7G on morphologic and ultra-structure changes of P. italicum were observed using both scanning electron microscopy (SEM) and transmission electron microscopy (TEM). SEM (JSM-6360LV, JEOL Ltd., Tokyo, Japan) and TEM (JEM-1400, JEOL Ltd., Tokyo, Japan) were used to observe the P. italicum mycelia treated with P7G at different concentrations $\left(0, \mathrm{EC}_{50}\right.$, and MIC), following the methods previously reported by Tao et al. [32] with some modifications.

For SEM preparation, about $1.0 \mathrm{~g}$ of mycelia were collected from P7G-treated and control PDB medium and promptly fixed with $0.1 \mathrm{M}$ phosphate-buffered saline (PBS; pH 7.2) containing $3.0 \%(v / v)$ glutaraldehyde at $4{ }^{\circ} \mathrm{C}$ for $8 \mathrm{~h}$. To remove glutaraldehyde, the fixed mycelia was washed five times with 0.1 M PBS (pH 7.2) followed by gradient ethanol elution $(30 \%, 50 \%, 70 \%, 80 \%, 90 \%$, and $100 \%$, $v / v)$, for $15 \mathrm{~min}$ in each ethanol dilution. The specimens were immersed in an iso-amyl acetate solution for $20 \mathrm{~min}$, and finally dried in a critical point drier (CPD; Samdri-795, Tousimis Co., LTD, Rockville, America). Following gold-coating, the prepared samples were observed by SEM operating at a $1500 \times$ magnification.

For TEM preparation, the dehydrated samples were passed through the solution of epoxy propane and epoxy resin (1:1) for $2 \mathrm{~h}$, and then embedded in pure epoxy media for $12 \mathrm{~h}$. Following polymerization at $37^{\circ} \mathrm{C}$ for $12 \mathrm{~h}, 45^{\circ} \mathrm{C}$ for $12 \mathrm{~h}$, and $60^{\circ} \mathrm{C}$ for $48 \mathrm{~h}$, the prepared specimens were double-stained with $3 \%(\mathrm{~m} / \mathrm{v})$ uranyl acetate and lead citrate, and finally observed by TEM operating at a $15000 \times$ magnification.

\subsection{Determination of Cell Membrane Permeability}

The extracellular conductivity (EC) of $P$. italicum mycelia was determined using an electrical conductivity meter (ST3100c/F, Ohaus Co., Ltd., New Jersey, America) following P7G treatment by a previous method with minor alterations [3]. The extracellular conductivity was observed at $0,1,2$, 4 and $6 \mathrm{~h}$ for the P7G-treated and the control groups, and results showed extracellular conductivity $(\mu \mathrm{s} / \mathrm{cm})$.

The rate of cell lysis rate in the P7G-treated and control groups was examined using a spectrophotometer. The level of cell lysis was explained as the difference between the initial and final absorbance recorded at $650 \mathrm{~nm}$, and the calculations were made using the following formula:

$$
\text { Cell lysis rate }(\mathrm{CLR}, \%)=\frac{\mathrm{At}-\mathrm{A} 0}{\mathrm{~A} 0} \times 100
$$

where At and A0 are the absorbance determined for the P7G-treated and control PDB groups, respectively. 
The nucleic acid leakage from P. italicum mycelia due to the P7G treatment was detected following the method given by Huang and colleagues [33], with slight modifications. The absorbance at $260 \mathrm{~nm}$ was examined at $0,1,2,4$ and $6 \mathrm{~h}$, and the leakage of nucleic acids from the P7G-treated and control group supernatants was expressed as $\mathrm{OD}_{260}$.

\subsection{Measurement of Intracellular Constituent Contents}

\subsubsection{Mycelial Growth Weight}

The effect of P7G on the mycelial growth weight of P. italicum was evaluated according to the method described previously by Chen et al. [29], with minor modifications, and the data were expressed as the mycelial volume (dry weight) based on $100 \mathrm{~mL}$ PDA $(\mathrm{g} / 100 \mathrm{~mL})$.

\subsubsection{Evaluation of Soluble Protein and Reducing Sugar Levels}

The contents of soluble protein and reducing sugar in P. italicum mycelia treated with P7G at various concentrations $\left(0, \mathrm{EC}_{50}\right.$ and $\left.\mathrm{MIC}\right)$ were determined using the method described by Chen et al. [3] with minor modifications, and were measured to calculate the soluble protein and reducing sugar contents $(\mathrm{mg} / \mathrm{g})$ using the standards of bovine serum albumin and glucose, respectively.

\subsubsection{Total Lipid Content}

The total lipid content of P. italicum mycelia with P7G at various concentrations $\left(0, \mathrm{EC}_{50}\right.$, and MIC) was identified using the method as described by Tao et al. [32], and expressed as milligrams per gram (mg/g) of frozen weight.

\subsection{Assays of Cell Wall Components Content and Enzyme Activities}

The contents of cell wall components in P. italicum mycelia treated with P7G at $0, \mathrm{EC}_{50}$, and MIC were determined using the method described by Stalhberger et al. [34], with minor modifications. The chitin content was measured using D-glucosamine sulfate as a standard, and the glucanase content was calculated as the sum of alkali soluble and insoluble sugar contents and was expressed as milligrams per gram $(\mathrm{mg} / \mathrm{g})$.

The activities of chitinase (CHI) and $\beta$-1,3-glucanase ( $\beta$-Glu) were determined by our previously described method [30]. One unit of the above two activities was equal to the amount of enzyme that catalyzed the production of $1.0 \mathrm{nM} \mathrm{N}$-acetyl-d-glucosamine (GlcNAc) and $1 \mu \mathrm{g}$ of reducing sugar per min of $1 \mathrm{~g}$ fresh weight mycelia. Both $\mathrm{CHI}$ and $\beta-\mathrm{Glu}$ activities were expressed as $\mathrm{U} / \mathrm{g}$ of frozen weight.

\subsection{Statistical Analysis}

All experimental data are reported as the means \pm standard error (S.E.) and were analyzed using SPSS version 17.0 (SPSS Inc., Chicago, IL, USA). Data from extracellular conductivity, cell lysis rate, nucleic acid leakage, mycelial growth weight, soluble protein content, reducing sugar content, cell wall component contents, and related enzyme activities assays were analyzed using Duncan's test, and significant differences were observed by applying one-way analysis of variance at the $5 \%$ level.

\section{Results}

\subsection{P7G Displays Potential Used as Antifungal Agent in Citrus Phytopathogenic Fungi}

Based on the observations of six tested phytopathogenic fungi growth on PDA medium containing various concentrations $(0,0.025,0.05,0.1,0.2,0.4$, and $0.8 \mathrm{~g} / \mathrm{L})$ of P7G during incubation at $25{ }^{\circ} \mathrm{C}$, P7G had strong inhibitory effect as MIC and MFC against six tested phytopathogenic fungi in citrus fruit. As shown in Table 1, the values of MIC and MFC of P7G against the tested fungi of $A$. citri, C. gloeosporioides, D. citri, G. citri-aurantii, P. digitatum, and P. italicum were found in the range of 0.1 to $0.8 \mathrm{~g} / \mathrm{L}$. In this assay, Diaporthe citri was found as the most susceptible fungus to P7G with the lowest 
MIC value $(0.1 \mathrm{~g} / \mathrm{L})$. Among these phytopathogenic fungi, A. citri showed the least susceptibility to P7G with the highest MIC and MFC value $(0.8 \mathrm{~g} / \mathrm{L})$. These results are in line with our previous study of clove essential oil (CEO) [35], and indicating that the in vitro antifungal efficiency of CEO may be similar and better than traditional citrus preservatives, with the values of MIC against P. italicum, P. digitatum, G. citri-aurantii, and A. citri ranging from 0.2 to $1.0 \mathrm{~mL} / \mathrm{L}$. Peng et al. [36] also reported that pinocembrin had potent antifungal activity against $P$. italicum, with MIC of $0.4 \mathrm{~g} / \mathrm{L}$. Our results suggested that P7G, as a flavonone derived from F. hirta Vahl. fruits, could be used as a novel antifungal agent to control citrus postharvest diseases.

Table 1. Determination of minimal inhibitory concentration (MIC) and minimum fungicidal concentration (MFC) values of pinocembrin-7-glucoside (P7G) against postharvest pathogenic fungi in citrus fruit.

\begin{tabular}{|c|c|c|c|c|c|c|c|}
\hline \multirow{2}{*}{\multicolumn{2}{|c|}{$\begin{array}{c}\text { Concentration of } \\
\text { P7G }(\mathrm{g} / \mathrm{L})\end{array}$}} & \multicolumn{6}{|c|}{ Pathogenic Fungus } \\
\hline & & $\begin{array}{l}\text { Alternaria } \\
\text { citri }\end{array}$ & $\begin{array}{l}\text { Colletotrichum } \\
\text { gloeosporioides }\end{array}$ & $\begin{array}{l}\text { Diaporthe } \\
\text { citri }\end{array}$ & $\begin{array}{l}\text { Geotrichum } \\
\text { citri-aurantii }\end{array}$ & $\begin{array}{l}\text { Penicillium } \\
\text { digitatum }\end{array}$ & $\begin{array}{l}\text { Penicillium } \\
\text { italicum }\end{array}$ \\
\hline \multirow{7}{*}{$\begin{array}{l}\text { Mycelial } \\
\text { growth for } \\
\text { 2nd d }\end{array}$} & 0 & + & + & + & + & + & + \\
\hline & 0.025 & + & + & + & + & + & + \\
\hline & 0.05 & + & + & + & + & + & + \\
\hline & 0.1 & + & + & - & + & + & + \\
\hline & 0.2 & + & - & - & - & - & - \\
\hline & 0.4 & + & - & - & - & - & - \\
\hline & 0.8 & - & - & - & - & - & - \\
\hline \multirow{7}{*}{$\begin{array}{l}\text { Mycelial } \\
\text { growth for } \\
\text { 6th d }\end{array}$} & 0 & + & + & + & + & + & + \\
\hline & 0.025 & + & + & + & + & + & + \\
\hline & 0.05 & + & + & + & + & + & + \\
\hline & 0.1 & + & + & + & + & + & + \\
\hline & 0.2 & + & + & + & + & + & + \\
\hline & 0.4 & + & - & - & + & - & + \\
\hline & 0.8 & - & - & - & - & - & - \\
\hline \multirow{2}{*}{\multicolumn{2}{|c|}{$\begin{array}{l}\text { MIC } \\
\text { MFC }\end{array}$}} & 0.8 & 0.2 & 0.1 & 0.2 & 0.2 & 0.2 \\
\hline & & 0.8 & 0.4 & 0.4 & 0.8 & 0.4 & 0.8 \\
\hline
\end{tabular}

Note: "+", presence of mycelia growth; "-", absence of mycelia growth.

\subsection{P7G has Antifungal Activity Against P. italicum}

As shown in Table 1 and Figure 2, the 0.2 and $0.8 \mathrm{~g} / \mathrm{L}$ P7G treatments completely inhibited P. italicum mycelial growth on the second and sixth days of incubation, respectively. Therefore, the values of MIC and MFC in response to P7G against $P$. italicum were 0.2 and $0.8 \mathrm{~g} / \mathrm{L}$, respectively.

As shown in Figure 2C, a significant inhibitory effect of P7G on P. italicum mycelial growth on PDA medium was seen in a dose-dependent fashion where the higher P7G concentration gave higher MGI. P7G at $0.2 \mathrm{~g} / \mathrm{L}$ could significantly suppress the mycelial growth of P. italicum, being inhibited by $74.7 \%$ compared with the control group (Figure $2 \mathrm{C}, p<0.05$ ), which was twice that of the MGI seen at $0.025 \mathrm{~g} / \mathrm{L}$ (36.9\%). Particularly, a complete inhibition of P. italicum mycelial growth was achieved at $0.8 \mathrm{~g} / \mathrm{L}$ of P7G. Furthermore, by calculating the MGI under different P7G concentrations, a linear regression of the MGI of $P$. italicum $(\mathrm{Y})$ on the log-transformed P7G concentrations $(\mathrm{X})$ was determined- $\mathrm{Y}=7.8219$ $+3.1150 \mathrm{X}, \mathrm{r}=0.9836$ (Figure 2C) - with the half maximal effective concentration (EC $\mathrm{EC}_{50}$ ) of P7G against P. italicum being $0.08 \mathrm{~g} / \mathrm{L}$. 

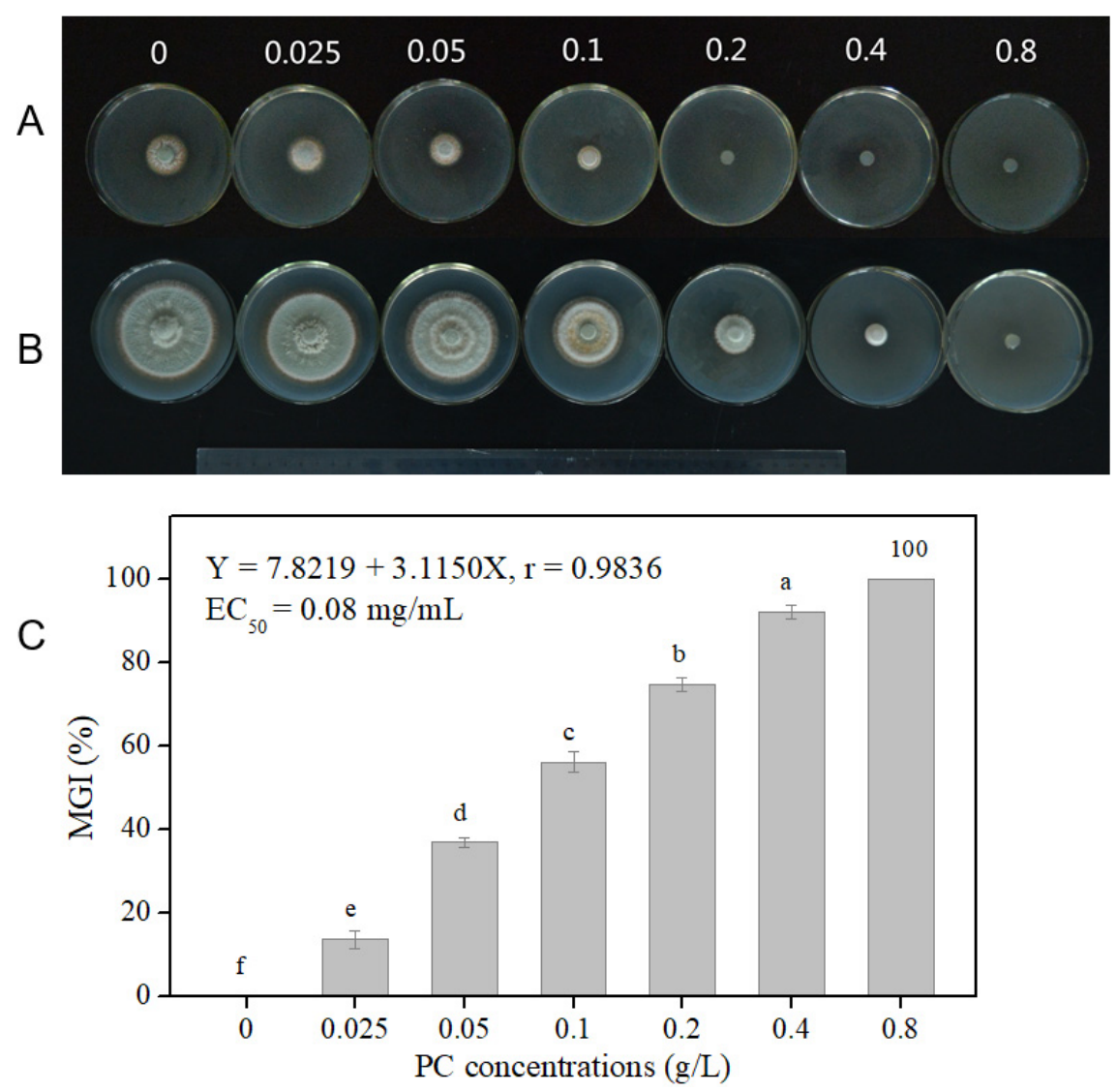

Figure 2. The minimal inhibitory concentration (MIC), the minimum fungicidal concentration (MFC) and the inhibitory effect of P7G against P. italicum on the second day (A), sixth day (B), and seventh day (C) after inoculation. Different letters $(\mathrm{a}-\mathrm{f})$ at each interval in Figure $1 \mathrm{C}$ indicate significant differences at $p<0.05$ according to Duncan's test.

The spore germination of $P$. italicum markedly decreased with increasing P7G-treated concentrations $(p<0.05$; Table 2). After incubation in PDB for $14 \mathrm{~h}$, the inhibitory rate of P. italicum spore decreased by more $50 \%$ in the presence of $0.05 \mathrm{~g} / \mathrm{L}$ P7G. When the P7G-treated concentration reached $0.4 \mathrm{~g} / \mathrm{L}$, P. italicum spore was germinated less than $5.0 \%$, whereas a complete inhibitory rate $(100 \%)$ was attained by the P7G-treated concentration at $0.8 \mathrm{~g} / \mathrm{L}$ (Table 2).

Table 2. Inhibitory effect of P7G on spore germination of P. italicum.

\begin{tabular}{cccc}
\hline $\begin{array}{c}\text { P7G Concentration } \\
(\mathbf{m g} / \mathbf{m L})\end{array}$ & $\begin{array}{c}\text { Spore Germination } \\
\mathbf{( \% )}\end{array}$ & $\begin{array}{c}\text { Inhibitory Rate } \\
\mathbf{( \% )}\end{array}$ & $\mathbf{E C}_{\mathbf{5 0}} \mathbf{( m g / m L )}$ \\
\hline 0 & $93.40 \pm 1.90 \mathrm{a}$ & $0.00 \pm 0.00 \mathrm{~g}$ & \\
0.025 & $67.17 \pm 2.05 \mathrm{~b}$ & $28.09 \pm 2.20 \mathrm{f}$ & \\
0.05 & $46.50 \pm 1.60 \mathrm{c}$ & $50.21 \pm 1.71 \mathrm{e}$ & \\
0.1 & $24.60 \pm 1.20 \mathrm{~d}$ & $73.66 \pm 1.28 \mathrm{~d}$ & 0.032 \\
0.2 & $13.92 \pm 0.87 \mathrm{e}$ & $85.10 \pm 0.94 \mathrm{c}$ & \\
0.4 & $3.50 \pm 0.20 \mathrm{f}$ & $96.25 \pm 0.21 \mathrm{~b}$ & \\
0.8 & $0.00 \pm 0.00 \mathrm{~g}$ & $100.00 \pm 0.00 \mathrm{a}$ & \\
\hline
\end{tabular}

Data represent the mean \pm standard error (S.E.; $n=4)$. Different letters $(a-g)$ indicate significant differences at $p<0.05$ according to Duncan's test.

\subsection{P7G Inhibits Blue Mold Development on Navel Orange Infected with P. italicum}

To certificate the antifungal efficacy of P7G for controlling postharvest blue mold caused by P. italicum in citrus fruit, we implemented an in vivo test on "Newhall" navel oranges. As shown 
in Figure 3A, blue mold symptoms and disease development in 'Newhall' navel orange wounds inoculated with P. italicum were significantly $(p<0.05)$ inhibited by P7G in a dose-dependent manner, suggesting a strong antifungal effect against $P$. italicum. The lesion diameter of blue mold infection in P7G-treated fruit at concentrations of 1, 2, 4, and $8 \mathrm{~g} / \mathrm{L}$ were $50.0 \%, 62.3 \%, 94.3 \%$, and 98.4\% smaller $(p<0.05)$ than that in the control fruit at day three after inoculation, respectively (Figure 3B). Likewise, P7G treatment with different concentrations significantly reduced disease severity in "Newhall" navel orange wounds inoculated with P. italicum $(p<0.05)$. The development of blue mold in "Newhall" navel oranges was significantly affected by P7G in a dose-dependent manner $(p<0.05)$. Among the test concentrations, over five MFC P7G treatments $(4 \mathrm{~g} / \mathrm{L}$ and $8 \mathrm{~g} / \mathrm{L})$ showed the greatest inhibitory effect, and had no significant differences in disease severity among the three time points of days three, five and seven after inoculation, respectively (Figure 3C). Based on the above results, the optimal inhibitory concentration of P7G for controlling postharvest blue mold of "Newhall" navel oranges caused by P. italicum was $4 \mathrm{~g} / \mathrm{L}$.

\section{A Control P7G at $1 \mathrm{~g} / \mathrm{L} \quad$ P7G at $2 \mathrm{~g} / \mathrm{L} \quad$ P7G at $4 \mathrm{~g} / \mathrm{L} \quad$ P7G at $8 \mathrm{~g} / \mathrm{L}$}
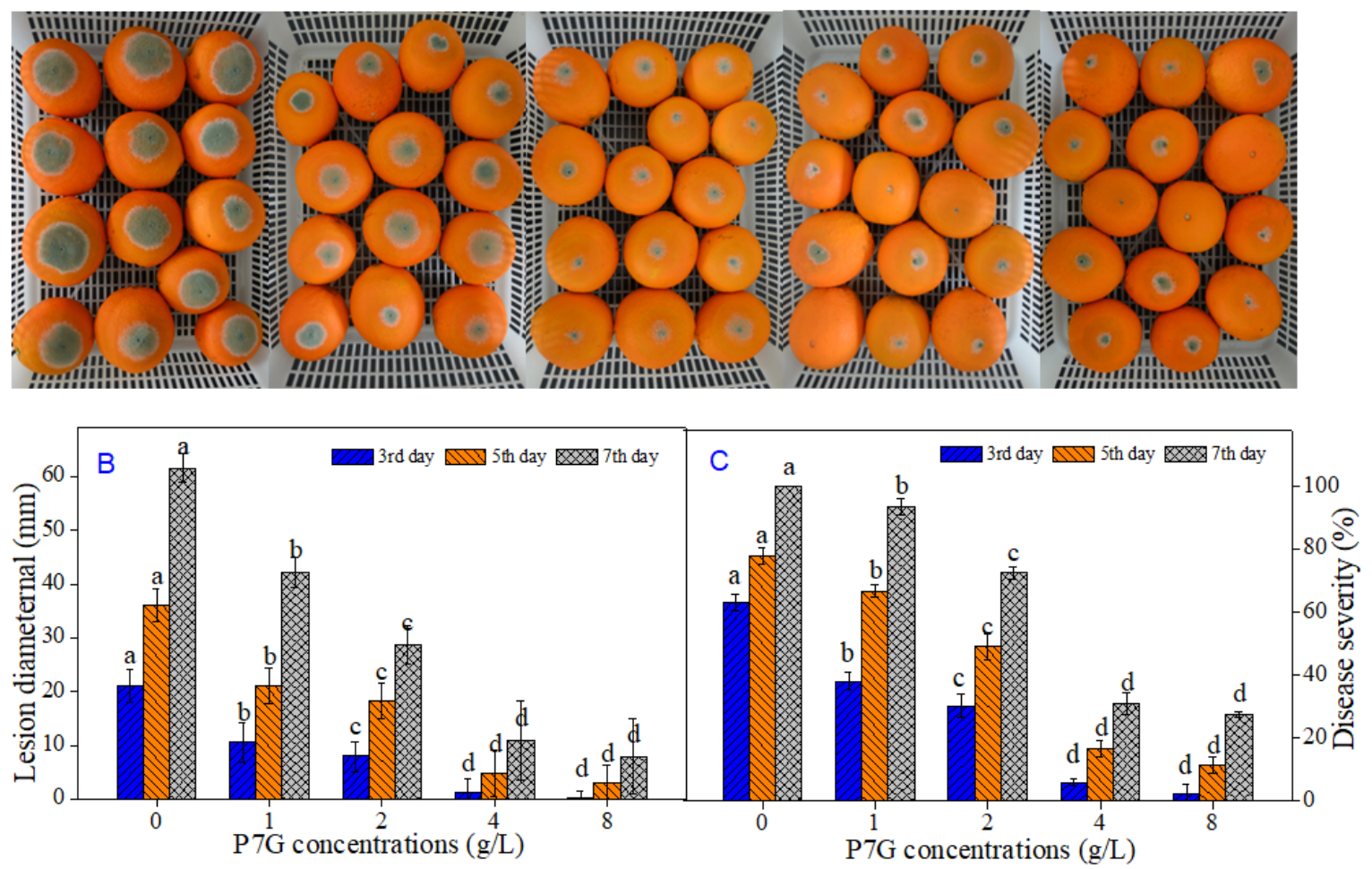

Figure 3. Effects of P7G at concentrations of 1-8 g/L on blue mold disease development of "Newhall" navel oranges wounds inoculated with P. italicum. Lesion diameter $(\mathbf{B})$ and disease severity $(\mathbf{C})$ were measured after 3, 5, and 7 days of incubation at $25^{\circ} \mathrm{C}$. Each column is the mean of three replicates (10 oranges per replicate), and vertical bars represent the standard error (S.E.). The columns with different lowercase letters among each concentration at each time point are significantly different according to Duncan's test at $p<0.05$.

\subsection{P7G Alters the Morphology and Ultrastructure of P. italicum}

To explore the antifungal mechanism of P7G against $P$. italicum, the morphology and ultrastructure of P. italicum mycelia and cells treated with P7G at various concentrations $\left(0, \mathrm{EC}_{50}\right.$ and MIC) were observed by SEM and TEM, respectively. The control mycelia of P. italicum grown in PDB showed smooth and homogeneous mycelial morphology (Figure 4A), with a typical fungal ultrastructure, abundant cytoplasmic matrix, and ordered division (Figure 4B). By contrast, these normal mycelial morphology and cell structures were changed conspicuously when exposed to P7G. Those treated 
with P7G at $\mathrm{EC}_{50}(0.08 \mathrm{~g} / \mathrm{L})$ had an obvious buckling, abnormal enlargement of the growing point, and a rough surface (Figure $4 \mathrm{C}$ ); meanwhile, the cell membrane collapsed, and degradation of cytoplasmic organelles led to the appearance of large vacuoles (Figure 4D). Furthermore, the mycelia of P. italicum treated with P7G at MIC $(0.2 \mathrm{~g} / \mathrm{L})$ were greatly damaged, and some of them parted and broke (Figure 4E); these destroyed phenomena of plasmolysis, indistinct organelles, thinned cell wall, infrequent cytoplasmic matrix, and cell permeabilization appeared in P. italicum cells treated with $0.2 \mathrm{~g} / \mathrm{L}$ of P7G (Figure 4F).
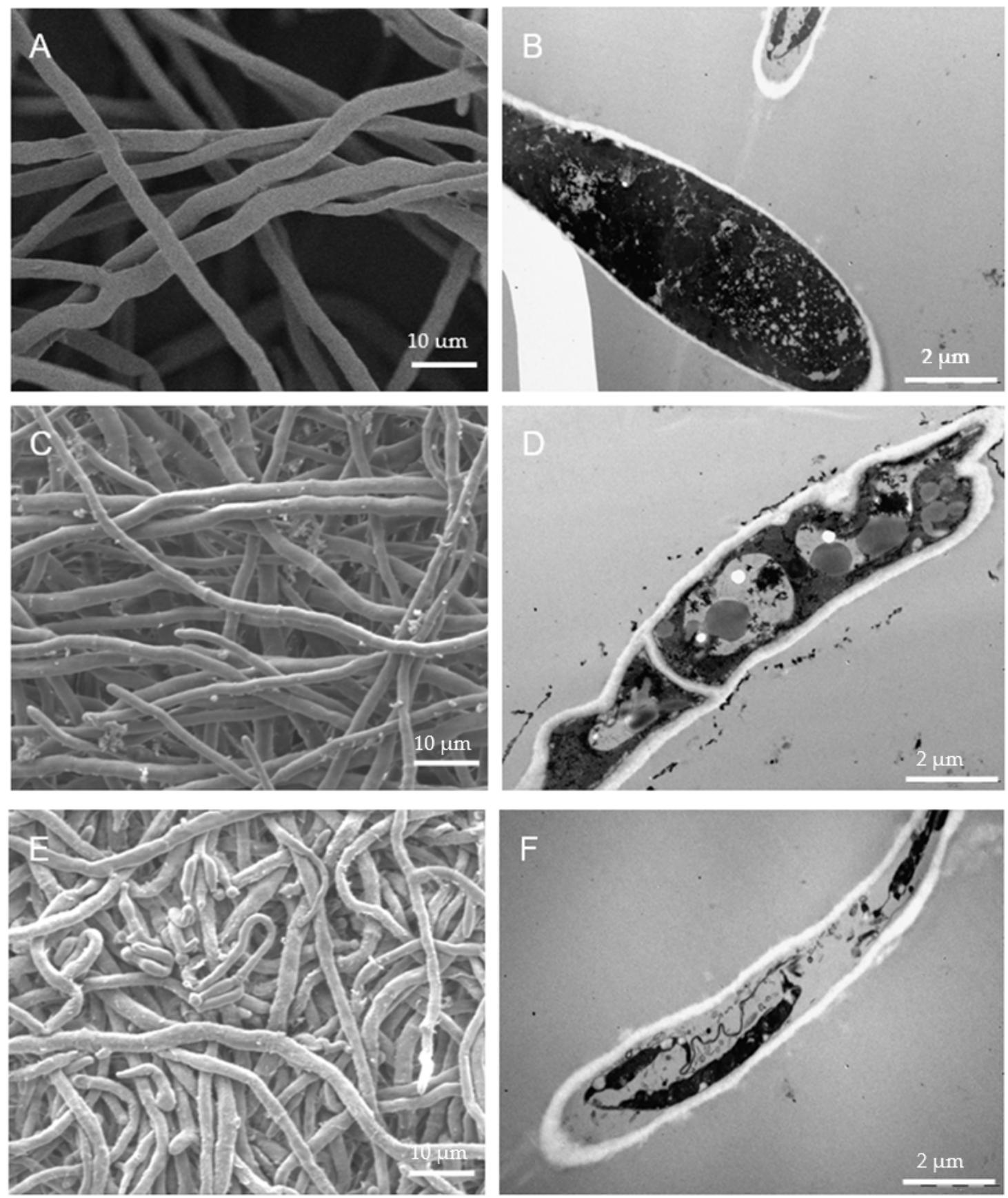

Figure 4. Scanning electron microscopy (SEM) and transmission electron microscopy (TEM) images of P7G against P. italicum. (A, B) Control mycelia and cells; (C, D) mycelia and cells treated with P7G at $\mathrm{EC}_{50}$; (E, F) mycelia and cells treated with P7G at MIC. 


\subsection{P7G Causes Cell Membrane Damage of P. italicum}

To further investigate the damage of the cell membrane induced by P7G treatment, the extracellular conductivity (EC), cell lysis rate and nucleic leakage of P. italicum were tested, all of which have been frequently used for determining the damage of membrane permeability. The EC of P. italicum supernatant treated with P7G at different concentrations $\left(0, \mathrm{EC}_{50}\right.$, and $\left.\mathrm{MIC}\right)$ for an inoculation period of 0-6 h was depicted in Figure 5A, and increased constantly with P7G-treated time. The electrical conductivity of 0.08 and $0.2 \mathrm{~g} / \mathrm{L}$ P7G-treated P. italicum supernatant was $153.3 \mu \mathrm{s} / \mathrm{cm}$ and $175.1 \mu \mathrm{s} / \mathrm{cm}$, respectively after $6 \mathrm{~h}$ of P7G treatment, being about 2.11 and 2.42 times higher than that of the control samples $(72.5 \mu \mathrm{s} / \mathrm{cm} ; p<0.05)$. As demonstrated in Figure $5 \mathrm{~B}$, the cell lysis rate in P. italicum supernatant treated with P7G exhibited obvious increases compared to the control samples particularly, which reached the highest value after $4 \mathrm{~h}$ of P7G treatment and was maintained at higher levels by P7G treatment with MIC $(0.2 \mathrm{~g} / \mathrm{L})$ than that in $\mathrm{EC}_{50}(0.08 \mathrm{~g} / \mathrm{L})$. Simultaneously, the higher the treatment concentration of $\mathrm{P} 7 \mathrm{G}$, the greater the nucleic acid leakage from the P. italicum supernatant; the supernatant with P7G at EC $50(0.08 \mathrm{~g} / \mathrm{L})$ at $6 \mathrm{~h}$ of the incubation had an absorbance at $260 \mathrm{~nm}$ $\left(\mathrm{OD}_{260}\right)$ of 1.193 , which was significantly higher $(p<0.05)$ than that of the control samples $(1.085)$, but significantly lower than that with MIC of P7G. Nevertheless, the $\mathrm{OD}_{260}$ values of P. italicum supernatant had no significant difference between the P7G-treated and control samples before $1 \mathrm{~h}$ of P7G treatment (Figure 5C). Thus, P7G treatment contributed to increasing the extracellular conductivity, cell lysis rate, and nucleic acid leakage in P. italicum supernatant, resulting in membrane permeability damage.
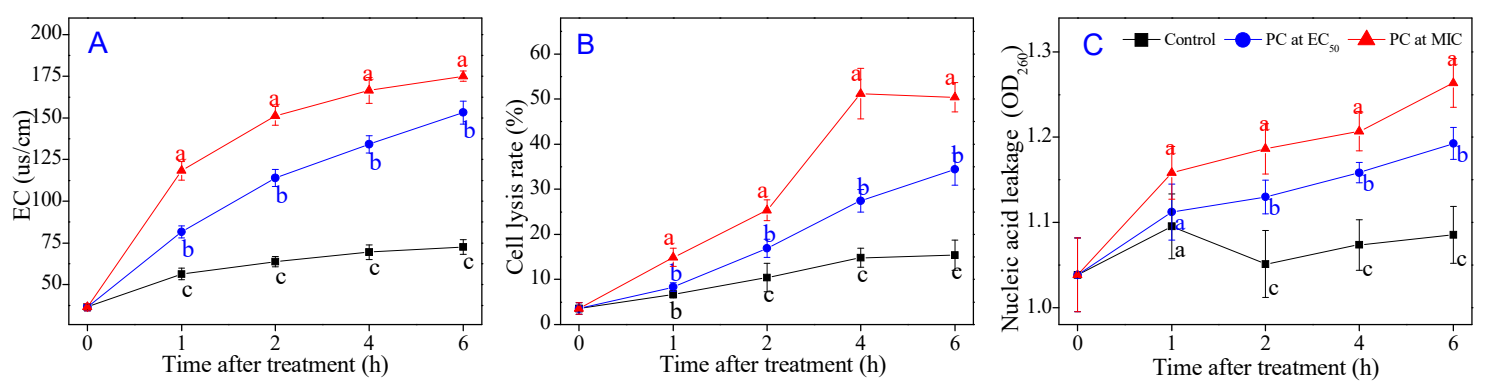

Figure 5. Effects of P7G on extracellular conductivity (A), cell lysis rate (B) and nucleic acid leakage (C) of P. italicum in potato dextrose broth (PDB). Each value is the mean of three replicates $(n=3)$, and the vertical bar indicates the standard error (S.E.). The values with different lowercase letters within the same time point indicate a significant difference between the control and the P7G-treated mycelia according to Duncan's test at $p<0.05$.

\subsection{P7G Induces the Outflow of Intercellular Inclusions of P. italicum}

Intracellular inclusions, as the indispensable material basis for the growth and reproduction of microorganisms, play a dominant role in biosynthesis, energy metabolism, and signal transduction. The present study evaluated the cell membrane damage of P7G on mycelial growth and intracellular constituent contents of P. italicum mycelia. As illustrated in Figure 6A, P7G treatment significantly suppressed the mycelial growth of P. italicum in PDB $(p<0.05)$. After $6 \mathrm{~h}$ of P7G treatment, the mycelial growth weight of $P$. italicum was $0.870 \pm 0.027 \mathrm{~g} /(100 \mathrm{~mL})$ and $0.618 \pm 0.013 \mathrm{~g} /(100 \mathrm{~mL})$ when the treatment concentration of P7G was $0.08 \mathrm{~g} / \mathrm{L}$ and $0.2 \mathrm{~g} / \mathrm{L}$, which was significantly lower than that in the control samples $(0.957 \pm 0.017 \mathrm{~g} /(100 \mathrm{~mL}) ; p<0.05)$. After being re-culture for 12 and $24 \mathrm{~h}$, the mycelial growth weight of P. italicum treated with P7G at MIC $(0.2 \mathrm{~g} / \mathrm{L})$ had no significant difference. As demonstrated in Figure $6 \mathrm{~B}-\mathrm{D}$, the contents of reducing sugar, soluble protein and total lipid in the control mycelia were found to maintain a steady upward level during the whole inoculation period. As shown in Figure 6B, the reducing sugar content in P. italicum mycelia significantly decreased from $15.10 \pm 0.31 \mathrm{mg} / \mathrm{g}$ without P7G to $19.47 \%$ and $27.15 \%$ with P7G at $\mathrm{EC}_{50}(0.08 \mathrm{~g} / \mathrm{L})$ and MIC $(0.2 \mathrm{~g} / \mathrm{L})$, respectively. Moreover, the reducing sugar content in 0.08 and $0.2 \mathrm{mg} / \mathrm{mL}$ P7G-treated P. italicum mycelia were $11.01 \pm 0.30 \mathrm{mg} / \mathrm{g}$ and $9.39 \pm 0.11 \mathrm{mg} / \mathrm{g}$, respectively after $6 \mathrm{~h}$ of P7G treatment, much 
lower than that in the control samples $(15.77 \pm 0.39 \mathrm{mg} / \mathrm{g})$. Similarly, the soluble protein content of P. italicum mycelia significantly decreased with P7G treatment at $\mathrm{EC}_{50}$ and MIC during the entire incubation (Figure $6 \mathrm{C}$ ). At the end of the inoculation period $(6 \mathrm{~h})$, the soluble protein content of the $0.08 \mathrm{~g} / \mathrm{L}$ and $0.2 \mathrm{~g} / \mathrm{L}$ P7G-treated P. italicum mycelia were $1.92 \pm 0.04 \mathrm{mg} / \mathrm{g}$ and $1.59 \pm 0.08 \mathrm{mg} / \mathrm{g}$, respectively, which were significantly lower than that in the control samples $(2.57 \pm 0.11 \mathrm{mg} / \mathrm{g} ; p<0.05)$. The effect of P7G at different concentrations $\left(0, \mathrm{EC}_{50}\right.$, and MIC) on the total lipid contents of P. italicum was shown in Figure 6D. The total lipid contents in P7G treatments were significantly lower than that in control samples during the entire incubation. After $6 \mathrm{~h}$ of P7G treatment, the total lipid contents in 0.08 and $0.2 \mathrm{~g} / \mathrm{L}$ P7G-treated P. italicum mycelia were $174.3 \pm 10.3 \mathrm{mg} / \mathrm{g}$ and $141.1 \pm 8.4 \mathrm{mg} / \mathrm{g}$, respectively, which were decreased by $34.30 \%$ and $46.81 \%$ compared to the control samples $(265.7 \pm 6.1 \mathrm{mg} / \mathrm{g}$ ). The above results were highly aligned with the microscopic observations in this study, and indicate that P7G treatment led to the inhibition of the synthesis of intracellular inclusions that caused cell membrane damage.
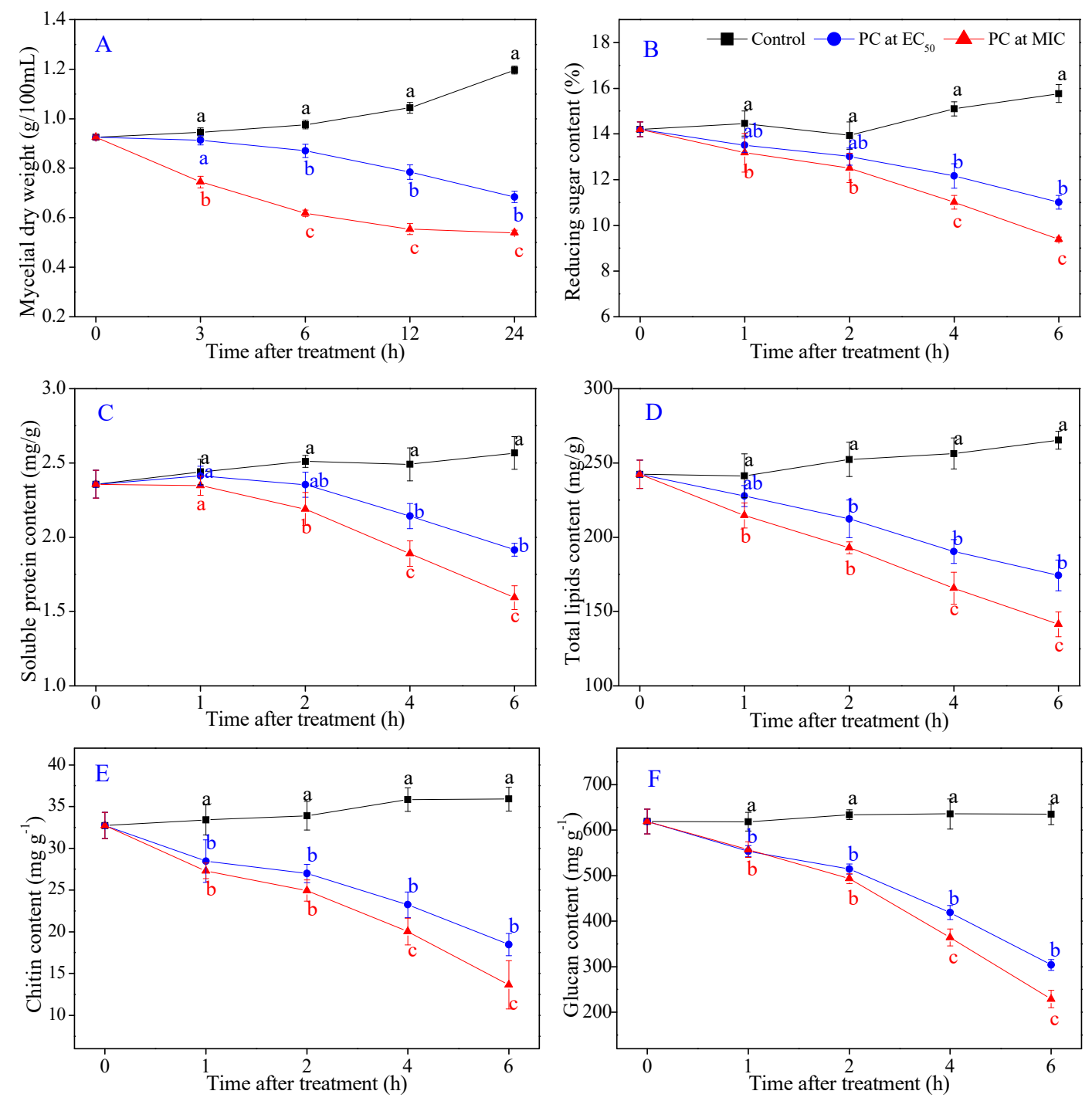

Figure 6. Effects of P7G on mycelial dry weight (A), reducing sugar content (B), soluble protein content (C), total lipid content (D), chitin content (E) and glucan content (F) of P. italicum in PDB. Each value is the mean of three replicates $(n=3)$, and the vertical bar indicates the standard error (S.E.). The values with different lowercase letters within the same time point indicate a significant difference between the control and the P7G-treated mycelia, according to Duncan's test at $p<0.05$. 


\subsection{P7G Modifies the Cell Wall Structure of P. italicum}

To further investigate the damage of the cell wall induced by P7G treatment, the cell wall constituent contents and degrading enzyme activities of P. italicum mycelia were tested, which are frequently used for determining the damage of the cell wall. As shown in Figure 6E, the chitin content in P. italicum mycelia treated with P7G at $\mathrm{EC}_{50}$ and MIC significantly declined to $18.48 \pm 1.33 \mathrm{mg} / \mathrm{g}$ and 13. $63 \pm 2.89 \mathrm{mg} / \mathrm{g}$, which were $48.52 \%$ and $60.03 \%$ lower than that of the control mycelia $(p<0.05)$, respectively. Similarly, a continuous decrease in the glucan content of P. italicum after P7G treatment was observed during the entire incubation, whereas the glucan content in control samples remained stable (Figure 6F). After P7G treatment for $6 \mathrm{~h}$, the glucan content in P. italicum mycelia treated with $\mathrm{EC}_{50}$ and MIC were $304.1 \pm 11.8 \mathrm{mg} / \mathrm{g}$ and $228.9 \pm 19.1 \mathrm{mg} / \mathrm{g}$, respectively, which were significantly lower than that in the control samples $(634.9 \pm 22.6 \mathrm{mg} / \mathrm{g} ; p<0.05)$.

As shown in Figure 7A,B, there was almost no change in the $\mathrm{CHI}$ and $\beta-\mathrm{Glu}$ activities in the control samples during the entire incubation. As illustrated by Figure 7A, the CHI activity in the control P. italicum mycelia began to decrease after $1 \mathrm{~h}$ of P7G treatment and remained stable thereafter, whereas the $\mathrm{CHI}$ activity of $P$. italicum mycelia treated with P7G at $\mathrm{EC}_{50}$ and $\mathrm{MIC}$ showed a significant uptrend after $1 \mathrm{~h}$ of the treatment. The $\beta$-Glu activity significantly increased in the $P$. italicum mycelia treated with $\mathrm{EC}_{50}$ and MIC of P7G at respective levels 1.13- and 1.36-fold higher than that in the control samples after $6 \mathrm{~h}$ (Figure 7B).
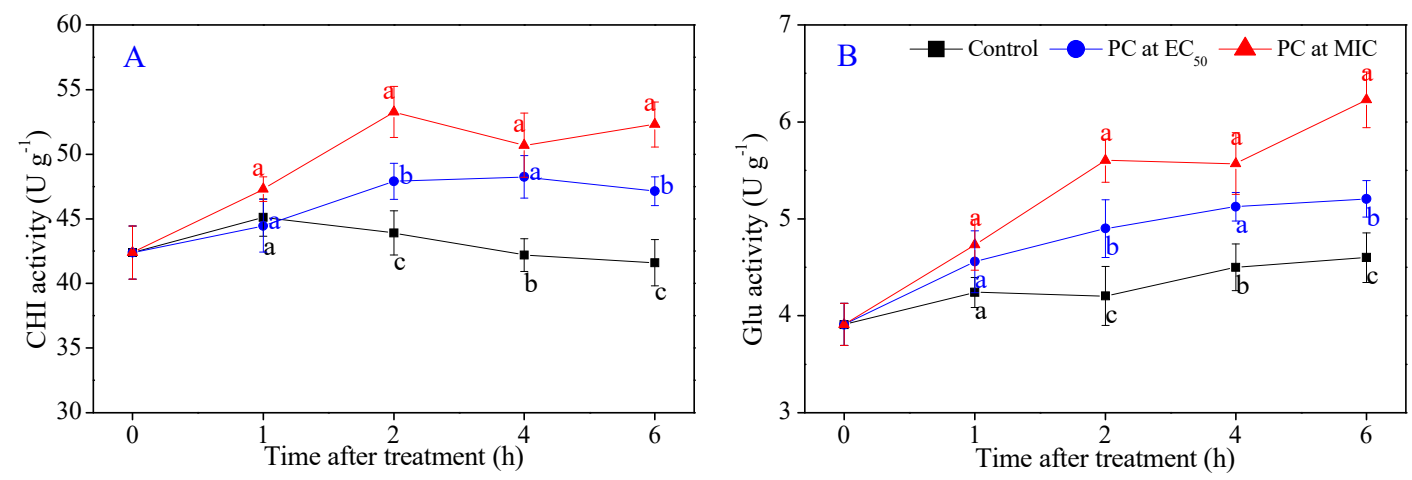

Figure 7. Effects of P7G on chitinase (CHI) activity (A) and $\beta$-1,3-glucanase ( $\beta$-Glu) activity (B) of P. italicum in PDB. Each value is the mean of three replicates $(n=3)$, and the vertical bar indicates the standard error (S.E.). The values with different lowercase letters within the same time point indicate a significant difference between the control and the P7G-treated mycelia, according to Duncan's test at $p<0.05$.

\section{Discussion}

Medicinal plant extracts and their bioactivators are being paid increasing attention by researchers due to their potential to control fungal growth as well as their preservative effects $[3,21,25,30,37,38]$. Among plant extracts, Ficus hirta Vahl. fruit is a common medicine and food that is widely distributed in southern China, and has gained a great deal of attention as an alternative antifungal agent due to its antifungal and antioxidant capacity owing to its high flavonoid content [18,23,31]. In our previous study, we confirmed that P7G isolated from F. hirta Vahl. fruit displayed a significant antifungal activity against postharvest pathogens of citrus fruit, especially for P. italicum $[18,23,29]$. To the best of our knowledge, no studies on the antifungal efficacy and possible mechanisms of P7G against this pathogen have yet been reported. In the current study, we showed that P7G had a prominent in vitro inhibitory effect on the mycelial growth, spore germination, mycelium morphology, cell ultrastructure, membrane permeability, intracellular constituents contents and cell wall degrading enzymes activities of P. italicum. In addition, P7G treatment showed in vivo antifungal efficacy in reducing postharvest blue mold of citrus fruit. 
The in vitro antifungal inhibition of P7G on mycelial growth and spore germination of P. italicum was shown to be in a prominent dose-dependent manner. Furthermore, in the in vitro study, our results demonstrated that, in comparison with the control group, the colony diameter of $P$. italicum dropped to $50 \%$ when P7G achieved $0.08 \mathrm{~g} / \mathrm{L}$ on PDA; meanwhile, the germination rate of P. italicum spore was suppressed by half in $0.032 \mathrm{~g} / \mathrm{L}$ P7G in PDB, indicating that in comparison to mycelia, the spore germination of P. italicum was more sensitive to P7G treatment (Figure 2 and Table 2). P7G gave lower MIC and MFC values of 0.2 and $0.8 \mathrm{~g} / \mathrm{mL}$, respectively, and showed higher antifungal activity against $P$. italicum than that determined for some other plant-derived antifungal active compounds (e.g., $\alpha$-terpineol and pinocembrin) assayed in previous studies $[36,39]$. For example, the effective antifungal concentration of the commonly used fungicide imazalil (IMZ) against green and blue molds requires $0.4 \mathrm{~g} / \mathrm{L}$ [40]. In the in vivo experiments herein, P7G treatment significantly reduced the lesion diameter and disease development of blue mold in "Newhall" navel orange wounds inoculated with P. italicum, with a lower disease severity of P7G-treated $(5 \times$ and $10 \times$ MFC) fruit of only $30.9 \pm 3.7 \%$ and $27.4 \pm 1.0 \%$ after 7 days post inoculation (Figure 3), which is consistent with those previously reported [41-44]. Recent studies have reported the antifungal potential of P7G in citrus fruit, while the results of the current study showed a strong check on the disease development of blue mold in citrus fruit and in vitro growth of P. italicum when exposed to various concentrations of P7G. Therefore, it is suggested that P7G could be a natural alternative for routine synthetic antifungal agents to control the growth of P. italicum, which causes postharvest blue mold rot in citrus fruit and its related horticultural products $[45,46]$.

This is a neoteric study in which P7G treatment was shown to have an effective in vivo control efficacy and in vitro inhibitory effect. Thus, the antifungal mechanisms of P7G deserve to be further elucidated. In general, flavonoids can inhibit the growth of phytopathogens, particularly fungal pathogens, mainly by damaging the cell membranes [47]. Numerous reports have elucidated the antifungal properties of natural antifungal compounds sourced from different plant extracts or essential oils that are largely due to the damage of the cell membrane $[28,33,48]$. In our study, the SEM images showed that P7G notably caused the formation of a rough surface and irregular shrinkage of P. italicum mycelia (Figure 4). These findings were also confirmed by the results of TEM analysis of P. italicum cells in which plasmolysis, indistinct organelles, outflowed cytoplasmic matrixces, thinned cell walls, and cavitation were observed in P7G-treated cells (Figure 4D,F). The observed changes in P7G-treated mycelia and cells may be due to an increase in cell permeabilization. Thus, we inferred that the in vitro antifungal mechanism of P7G against $P$. italicum may be associated with the dissociation of the fungal cell membranes.

Fungal cell membranes have a vital function in maintaining the relative stability of the cell cytoplasm, and previous studies have reported that various natural plant-derived compounds are potential fungicides and fungistats that directly or indirectly target the cell membrane or its components to disrupt membrane permeability, to destroy the membrane structure, and to cause leakage of nucleic acids $[28,32,33]$. Membrane permeability parameters, including changes in extracellular conductivity, cell lysis rate, and the leakage of nucleic acids, were used to verify this phenomenon. Sugars, proteins and lipids are the primary components of cell membranes, and the loss of cell membrane components can typically indicate irreversible damage to the cell membrane [3,32,49]. In the present study, P7G treatment led to a rapid, significant increase in the extracellular conductivity, cell lysis rate, and nucleic acid leakage in P. italicum supernatants (Figure 5), as well as to a significant decrease in mycelial weight and in reducing sugar, soluble protein, and total lipid contents in P. italicum mycelia (Figure 6). Similar findings describing the inhibitory effects of cinnamaldehyde, citral and pinocembrin on P. italicum growth have been reported $[32,33,36]$. These findings indicate that membrane stability is an important antifungal target of P7G.

The cell wall is a specific organelle of fungi that plays an important role in maintaining the inherent form, integrity, and normal metabolism of fungal cells. Chitin and glucan are two of the primary components of fungal cell walls and are important indicators that reflect the growing states of 
phytopathogens [50]. Both $\mathrm{CHI}$ and $\beta$-Glu are considered to be two key cell wall-degrading enzymes that openly inhibit the growth of pathogens primarily by the decomposition of chitin and glucan in the cell wall of many pathogenic fungi [51]. In our study, both the chitin and glucan contents of P. italicum mycelia were significantly inhibited by P7G at $\mathrm{EC}_{50}$ and MIC (Figure $6 \mathrm{E}, \mathrm{F}$ ), suggesting that P7G treatment could significantly suppress the biosynthesis of chitin and glucan, which is highly consistent with a recent report by Ouyang et al. [52]. Moreover, P7G treatment significantly increased the activities of the two cell wall-degrading enzymes $\mathrm{CHI}$ and $\beta$-Glu in P. italicum mycelia compared to that observed in the control mycelia (Figure 7A,B). These results support the observed ultrastructure of P. italicum cells treated with P7G, which is in high agreement with a previous report by Li et al. [53]. Taken together, the observed decrease in cell wall contents and the increase in cell wall-degrading enzyme activities demonstrate that the fungal cell wall is a crucial antifungal target of P7G.

\section{Conclusions}

In summary, this study demonstrated that P7G is effective at inhibiting the in vitro mycelial growth of P. italicum, and hence controls the postharvest blue mold on citrus fruit. The SEM and TEM observations showed that P7G treatment damaged the morphology of $P$. italicum mycelia by increasing the leakage of cytoplasmic constituents, altering membrane permeability and destroying cell wall structure, resulting in P. italicum cell death. Taken together, the antifungal potential of P7G may be attributed to causing significant damage to the structures of fungal cell membrane, as well as cell wall. These results imply that P7G has the antifungal potential to be a promising novel botanical fungicide to control blue mold disease in citrus fruit; however, further studies are needed to assess its ability to promote "Newhall" navel orange preservation.

Author Contributions: Conceptualization, C.C. and J.C.; methodology, C.C.; validation, C.C., J.C. and C.W.; formal analysis, C.C.; investigation, C.W.; data curation, C.C. and C.W.; writing-original draft preparation, C.C.; writing-review and editing, C.W.; visualization, C.C.; supervision, C.W.; project administration, J.C.; funding acquisition, J.C. All authors have read and agreed to the published version of the manuscript.

Funding: This research was funded by the National Natural Science Foundation of China (No.31760598), and the Education Department, the Advantage Innovation Team Project of Jiangxi province (No. GJJ180175 and 20181BCB24005).

Conflicts of Interest: The authors declare no conflict of interest.

\section{References}

1. Jiang, C.C.; Zhang, Y.F.; Lin, Y.J.; Chen, Y.; Lu, X.K. Illuminafi Sequencing Reveals Candidate Genes of Carotenoid Metabolism in Three Pummelo Cultivars (Citrus Maxima) with Different Pulp Color. Int. J. Mol. Sci. 2019, 20, 2246. [CrossRef] [PubMed]

2. El-Otmani, M.; Ait-Oubahou, A.; Zacarías, L. Citrus Spp.: Orange, Mandarin, Tangerine, Clementine, Grapefruit, Pomelo, Lemon and Lime. In Postharvest Biology and Technology of Tropical and Subtropical Fruits; Yahia, E.M., Ed.; Woodhead Publishing: Cambridge, UK, 2011; pp. 437-516.

3. Chen, C.; Qi, W.; Peng, X.; Chen, J.; Wan, C. Inhibitory effect of 7-demethoxytylophorine on Penicillium italicum and its possible mechanism. Microorganisms 2019, 7, 36. [CrossRef] [PubMed]

4. Yang, Q.; Qian, X.; Dhanasekaran, S.; Boateng, N.A.S.; Yan, X.; Zhu, H.; He, F.; Zhang, H. Study on the infection mechanism of Penicillium digitatum on postharvest citrus (Citrus reticulata Blanco) based on transcriptomics. Microorganisms 2019, 7, 672. [CrossRef] [PubMed]

5. Dou, S.; Ouyang, Q.; You, K.; Qian, J.; Tao, N. An inclusion complex of thymol into $\beta$-cyclodextrin and its antifungal activity against Geotrichum citri-aurantii. Postharvest Biol. Tech. 2018, 138, 31-36. [CrossRef]

6. Xu, L.; Tao, N.; Yang, W.; Jing, G. Cinnamaldehyde damaged the cell membrane of Alternaria alternata and induced the degradation of mycotoxins in vivo. Ind. Crop. Prod. 2018, 112, 427-433. [CrossRef]

7. Galsurker, O.; Diskin, S.; Maurer, D.; Feygenberg, O.; Alkan, N. Fruit stem-end rot. Horticulturae 2018, 4, 50. [CrossRef] 
8. Erasmus, A.; Lennox, C.L.; Korsten, L.; Lesar, K.; Fourie, P.H. Imazalil resistance in Penicillium digitatum and P. italicum causing citrus postharvest green and blue mould: Impact and options. Postharvest Biol. Tech. 2015, 107, 66-76. [CrossRef]

9. Hao, W.; Zhong, G.; Hu, M.; Luo, J.; Weng, Q.; Rizwan-ul-Haq, M. Control of citrus postharvest green and blue mold and sour rot by tea saponin combined with imazalil and prochloraz. Postharvest Biol. Tech. 2010, 56, 39-43. [CrossRef]

10. Altieri, G.; Di Renzo, G.C.; Genovese, F.; Calandra, M.; Strano, M.C. A new method for the postharvest application of imazalil fungicide to citrus fruit. Biosyst. Eng. 2013, 115, 434-443. [CrossRef]

11. Tripathi, P.; Dubey, N.K. Exploitation of natural products as an alternative strategy to control postharvest fungal rotting of fruit and vegetables. Postharvest Biol. Tech. 2004, 32, 235-245. [CrossRef]

12. Talibi, I.; Boubaker, H.; Boudyach, E.; Ait Ben Aoumar, A. Alternative methods for the control of postharvest citrus diseases. J. Appl. Microbiol. 2014, 117, 1-17. [CrossRef] [PubMed]

13. Chen, J.; Shen, Y.; Chen, C.; Wan, C. Inhibition of key citrus postharvest fungal strains by plant extracts in vitro and in vivo: A review. Plants 2019, 8, 26. [CrossRef] [PubMed]

14. Yi, T.; Chen, Q.L.; He, X.C.; So, S.W.; Lo, Y.L.; Fan, L.L.; Xu, J.; Tang, Y.; Zhang, J.Y.; Zhao, Z.Z.; et al. Chemical quantification and antioxidant assay of four active components in Ficus hirta root using UPLC-PAD-MS fingerprinting combined with cluster analysis. Chem. Cent. J. 2013, 7, 1752-1760. [CrossRef]

15. Cheng, J.; Yi, X.; Chen, H.; Wang, Y.; He, X. Anti-inflammatory phenylpropanoids and phenolics from Ficus hirta Vahl. Fitoterapia 2017, 121, 229-234. [CrossRef]

16. Ya, J.; Zhang, X.Q.; Wang, Y.; Zhang, Q.W.; Chen, J.X.; Ye, W.C. Two new phenolic compounds from the roots of Ficus hirta. Nat. Prod. Res. 2010, 24, 621-625. [CrossRef]

17. Zeng, Y.W.; Liu, X.Z.; Lv, Z.C.; Peng, Y.H. Effects of Ficus hirta Vahl. (Wuzhimaotao) extracts on growth inhibition of Hela cells. Exp. Toxicol. Pathol. 2012, 64, 743-749. [CrossRef]

18. Chen, C.; Wan, C.; Peng, X.; Chen, Y.; Chen, M.; Chen, J. Optimization of antifungal extracts from Ficus hirta fruits using response surface methodology and antifungal activity tests. Molecules 2015, 20, 19647-19659. [CrossRef]

19. Chen, C.; Peng, X.; Zeng, R.; Chen, M.; Wan, C.; Chen, J. Ficus hirta fruits extract incorporated into an alginate-based edible coating for nanfeng mandarin preservation. Sci. Hortic. 2016, 202, 41-48. [CrossRef]

20. Chen, C.; Cai, N.; Chen, J.; Peng, X.; Wan, C. Chitosan-based coating enriched with hairy fig (Ficus hirta Vahl.) fruit extract for "Newhall" navel orange preservation. Coatings 2018, 8, 445. [CrossRef]

21. Chen, C.; Nie, Z.; Wan, C.; Chen, J. Preservation of xinyu tangerines with an edible coating using Ficus hirta Vahl. fruits extract-incorporated chitosan. Biomolecules 2019, 9, 46. [CrossRef]

22. Wang, Z.B.; Zhai, Y.D.; Ma, Z.P.; Yang, C.J.; Pan, R.; Yu, J.L.; Wang, Q.H.; Yang, B.Y.; Kuang, H.X. Triterpenoids and flavonoids from the leaves of astragalus membranaceus and their inhibitory effects on nitric oxide production. Chem. Biodivers. 2015, 12, 1575-1584. [CrossRef] [PubMed]

23. Wan, C.; Chen, C.; Li, M.; Yang, Y.; Chen, M.; Chen, J. Chemical constituents and antifungal activity of Ficus hirta Vahl. fruits. Plants 2017, 6, 44. [CrossRef] [PubMed]

24. Xu, H.; Zhao, B.; Wang, Y.; Lin, N.; Wang, L.; Song, T.; Yang, H. A new flavonoid glycoside and potential antifungal activity of isolated constituents from the flowers of Lilium lancifolium. J. Chem. Res. 2015, 39, 260-262. [CrossRef]

25. Yang, S.; Zhou, Y.; Ye, J.; Fan, G.; Peng, L.; Pan, S. Effects of poplar buds as an alternative to propolis on postharvest diseases control of strawberry fruits. J. Sci. Food Agric. 2016, 96, 2136-2141. [CrossRef] [PubMed]

26. Guo, W.; Wang, X.; Chen, X.; Ba, Y.; Zhang, N.; Xu, R.; Zhao, W.; Wu, X. Flavonones from Penthorum chinense ameliorate hepatic steatosis by activating the sirt1/ampk pathway in HepG2 cells. Int. J. Mol. Sci. 2018, 19, 2555. [CrossRef] [PubMed]

27. Cao, Y.W.; Jiang, Y.; Zhang, D.Y.; Wang, M.; Chen, W.S.; Su, H.X.; Wang, Y.T.; Wan, J.B. Protective effects of Penthorum chinense Pursh against chronic ethanol-induced liver injury in mice. J. Ethnopharmacol. 2015, 161, 92-98. [CrossRef]

28. Chen, C.; Wan, C.; Peng, X.; Chen, J. A flavonone pinocembroside inhibits Penicillium italicum growth and blue mold development in 'Newhall' navel oranges by targeting membrane damage mechanism. Pestic. Biochem. Phys. 2020. [CrossRef]

29. Chen, C.; Cai, N.; Chen, J.; Wan, C. UHPLC-Q-TOF/MS-based metabolomics approach reveals the antifungal potential of pinocembroside against citrus green mold phytopathogen. Plants 2020, 9, 17. [CrossRef] 
30. Chen, C.; Cai, N.; Chen, J.; Wan, C. Clove essential oil as an alternative approach to control postharvest blue mold caused by Penicillium italicum in citrus fruit. Biomolecules 2019, 9, 197. [CrossRef]

31. Chen, C.; Peng, X.; Chen, J.; Wan, C. Antioxidant, antifungal activities of ethnobotanical Ficus hirta Vahl. and analysis of main constituents by HPLC-MS. Biomedicines 2020, 8, 15. [CrossRef]

32. Tao, N.; OuYang, Q.; Jia, L. Citral inhibits mycelial growth of Penicillium italicum by a membrane damage mechanism. Food Control 2014, 41, 116-121. [CrossRef]

33. Huang, F.; Kong, J.; Ju, J.; Zhang, Y.; Guo, Y.; Cheng, Y.; Qian, H.; Xie, Y.; Yao, W. Membrane damage mechanism contributes to inhibition of trans-cinnamaldehyde on Penicillium italicum using Surface- Enhanced Raman Spectroscopy (SERS). Sci. Rep. 2019, 9, 490. [CrossRef] [PubMed]

34. Stalhberger, T.; Simenel, C.; Clavaud, C.; Eijsink, V.G.; Jourdain, R.; Delepierre, M.; Latgé, J.P.; Breton, L.; Fontaine, T. Chemical organization of the cell wall polysaccharide core of Malassezia restricta. J. Biol. Chem. 2014, 289, 12647-12656. [CrossRef]

35. Chen, C.; Zheng, J.; Wan, C.; Chen, M.; Chen, J. Effect of carboxymethyl cellulose coating enriched with clove oil on postharvest quality of 'Xinyu' mandarin oranges. Fruits 2016, 71, 319-327. [CrossRef]

36. Peng, L.; Yang, S.; Cheng, Y.J.; Chen, F.; Pan, S.; Fan, G. Antifungal activity and action mode of pinocembrin from propolis against Penicillium italicum. Food Sci. Biotech. 2012, 21, 1533-1539. [CrossRef]

37. Tayel, A.A.; Moussa, S.H.; Salem, M.F.; Mazrou, K.E.; El-Tras, W.F. Control of citrus molds using bioactive coatings incorporated with fungal chitosan/plant extracts composite. J. Sci. Food Agric. 2015, 96, 1306-1312. [CrossRef] [PubMed]

38. Liu, H.X.; Zhao, H.F.; Lyu, L.F.; Huang, Z.J.; Fan, S.F.; Wu, W.L.; Li, W.L. Synergistic effect of natural antifungal agents for postharvest diseases of blackberry fruits. J. Sci. Food Agric. 2019, 99, 3343-3349. [CrossRef]

39. Ouyang, Q.L.; Jia, L.; Tao, N.G.; He, X.L. Inhibitory effect of $\alpha$-terpineol on Penicillium italicum. J. Food Sci. 2014, 35, 32-35. [CrossRef]

40. D’Aquino, S.; Schirra, M.; Palma, A.; Angioni, A.; Cabras, P.; Migheli, Q. Residue levels and effectiveness of pyrimethanil vs imazalil when using heated postharvest dip treatments for control of Penicillium decay on citrus fruit. J. Agric. Food Chem. 2006, 54, 4721-4726. [CrossRef]

41. Pérez-Alfonso, C.O.; Martínez-Romero, D.; Zapata, P.J.; Serrano, M.; Valero, D.; Castillo, S. The effects of essential oils carvacrol and thymol on growth of Penicillium digitatum and P. italicum involved in lemon decay. Int. J. Food Microbiol. 2012, 158, 101-106. [CrossRef]

42. Li Destri Nicosia, M.G.; Pangallo, S.; Raphael, G.; Romeo, F.V.; Strano, M.C.; Rapisarda, P.; Droby, S.; Schena, L. Control of postharvest fungal rots on citrus fruit and sweet cherries using a pomegranate peel extract. Postharvest Biol. Tech. 2016, 114, 54-61. [CrossRef]

43. Duan, X.; Jing, G.; Fan, F.; Tao, N. Control of postharvest green and blue molds of citrus fruit by application of sodium dehydroacetate. Postharvest Biol. Tech. 2016, 113, 17-19. [CrossRef]

44. Wang, F.; Deng, J.; Jiao, J.; Lu, Y.; Yang, L.; Shi, Z. The combined effects of carboxymethyl chitosan and Cryptococcus laurentii treatment on postharvest blue mold caused by Penicillium italicum in grapefruit fruit. Sci. Hortic. 2019, 253, 35-41. [CrossRef]

45. Palou, L.; Ali, A.; Fallik, E.; Romanazzi, G. GRAS, plant- and animal-derived compounds as alternatives to conventional fungicides for the control of postharvest diseases of fresh horticultural produce. Postharvest Biol. Tech. 2016, 122, 41-52. [CrossRef]

46. Mari, M.; Bautista-Baños, S.; Sivakumar, D. Decay control in the postharvest system: Role of microbial and plant volatile organic compounds. Postharvest Biol. Tech. 2016, 122, 70-81. [CrossRef]

47. Yang, S.; Zhou, J.; Li, D.; Shang, C.; Peng, L.; Pan, S. The structure-antifungal activity relationship of 5,7-dihydroxyflavonoids against Penicillium italicum. Food Chem. 2017, 224, 26-31. [CrossRef]

48. Chen, Y.H.; Lu, M.H.; Guo, D.S.; Zhai, Y.Y.; Miao, D.; Yue, J.Y.; Yuan, C.H.; Zhao, M.M.; An, D.R. Antifungal effect of magnolol and honokiol from Magnolia officinalis on Alternaria alternata causing tobacco brown spot. Molecules 2019, 24, 2140. [CrossRef]

49. Carrasco, H.; Robles-Kelly, C.; Rubio, J.; Olea, A.F.; Martínez, R.; Silva-Moreno, E. Antifungal effect of polygodial on Botrytis cinerea, a fungal pathogen affecting table grapes. Int. J. Mol. Sci. 2017, 18, 2251. [CrossRef]

50. Sun, C.; Jin, L.; Cai, Y.; Zheng, X.; Yu, T. (1 $\rightarrow 3)-\beta$-d-glucan from yeast cell wall: Characteristic and potential application in controlling postharvest disease of pear. Postharvest Biol. Tech. 2019, 154, 105-114. [CrossRef] 
51. Bartnicki-Garcia, S. Cell wall chemistry, morphogenesis, and taxonomy of fungi. Ann. Rev. Microbiol. 1968, 22, 87-108. [CrossRef]

52. OuYang, Q.; Duan, X.; Li, L.; Tao, N. Cinnamaldehyde exerts its antifungal activity by disrupting the cell wall integrity of Geotrichum citri-aurantii. Front. Microbiol. 2019, 10, 9. [CrossRef] [PubMed]

53. Li, R.Y.; Wu, X.M.; Yin, X.H.; Liang, J.N.; Li, M. The natural product citral can cause significant damage to the hyphal cell walls of Magnaporthe grisea. Molecules 2014, 19, 10279-10290. [CrossRef] [PubMed]

(C) 2020 by the authors. Licensee MDPI, Basel, Switzerland. This article is an open access article distributed under the terms and conditions of the Creative Commons Attribution (CC BY) license (http://creativecommons.org/licenses/by/4.0/). 